\title{
Description of the mitochondrial genome of the tree coral Dendrophyllia arbuscula (Anthozoa, Scleractinia)
}

\section{Bruna Louise Pereira Luz, Kátia Cristina Cruz Capel, Sérgio Nascimento Stampar \& Marcelo Visentini Kitahara}

To cite this article: Bruna Louise Pereira Luz, Kátia Cristina Cruz Capel, Sérgio Nascimento Stampar \& Marcelo Visentini Kitahara (2016) Description of the mitochondrial genome of the tree coral Dendrophyllia arbuscula (Anthozoa, Scleractinia), Mitochondrial DNA Part A, 27:4, 2911-2912, DOI: $10.3109 / 19401736.2015 .1060435$

To link to this article: https://doi.org/10.3109/19401736.2015.1060435

\section{Published online: 29 Jun 2015.}

Submit your article to this journal ¿

Џ Article views: 62

View Crossmark data $\longleftarrow$

更

Citing articles: 1 View citing articles $\complement 7$ 


\title{
Description of the mitochondrial genome of the tree coral Dendrophyllia arbuscula (Anthozoa, Scleractinia)
}

\author{
Bruna Louise Pereira Luz ${ }^{1}$, Kátia Cristina Cruz Capel ${ }^{2}$, Sérgio Nascimento Stampar ${ }^{3}$, and Marcelo Visentini \\ Kitahara $^{1,4,5}$

\begin{abstract}
${ }^{1}$ Programa de Pós graduação em Sistemas Costeiros e Oceânicos, Centro de Estudos do Mar (CEM), Universidade Federal do Paraná, Pontal Rio de Janeiro, Brazil, ${ }^{3}$ Faculdade de Ciências e Letras de Assis, UNESP - Universidade Estadual Paulista, Assis, São Paulo, Brazil, ${ }^{4}$ Departamento
\end{abstract} \\ do Paraná, Paraná, Brazil, 'Programa de Pós graduação em Biodiversidade e Biologia Evolutiva, Universidade Federal do Rio de Janeiro, \\ de Ciências do Mar, Universidade Federal de São Paulo, Campus Baixada Santista, Santos, São Paulo, Brazil, and ${ }^{5}$ Centro de Biologia Marinha \\ (CEBIMar), Universidade de São Paulo, São Sebastião, São Paulo, Brazil
}

\begin{abstract}
Dendrophylliidae is one of the few monophyletic families within the Scleractinia that embraces zooxanthellate and azooxanthellate species represented by both solitary and colonial forms. Among the exclusively azooxanthellate genera, Dendrophyllia is reported worldwide from 1 to $1200 \mathrm{~m}$ deep. To date, although three complete mitochondrial $(\mathrm{mt})$ genomes from representatives of the family are available, only that from Turbinaria peltata has been formally published. Here we describe the complete nucleotide sequence of the $\mathrm{mt}$ genome from Dendrophyllia arbuscula that is $19069 \mathrm{bp}$ in length and comprises two rDNAs, two tRNAs, and 13 proteincoding genes arranged in the canonical scleractinian $\mathrm{mt}$ gene order. No genes overlap, resulting in the presence of 18 intergenic spacers and one of the longest scleractinian $\mathrm{mt}$ genome sequenced to date.
\end{abstract}

Keywords

Dendrophyllia arbuscula, mitochondrial genome, Scleractinia

\section{History}

Received 19 May 2015

Revised 1 June 2015

Accepted 6 June 2015

Published online 29 June 2015

\section{Introduction}

Comprising nearly 1500 recent species (Cairns, 1999), scleractinians are one of the main framework builders in marine ecosystems. Morphologically, the order is separated into 31 families of which, molecularly, are divides into three main clades - "'Basal', "Complex', and "Robust'" (Kitahara et al., 2010; Romano \& Palumbi, 1996; Stolarski et al., 2011). Within the "Complex" clade, the Dendrophylliidae comprises 20 genera and 166 species (Cairns, 1999, 2001, 2007) embracing zooxanthellate, azooxanthellate, and facultative representatives reported to shallow and deep waters. Although capturing the full spectrum of polyp integration, ranging from exclusively solitary to colonial representatives, complete mitochondrial (mt) sequence has been formally published for only one representative of the family, the zooxanthellate Turbinaria peltata (Shi et al., 2014). Using scleractinian mt universal primers (Lin et al., 2011) in addition to the development of five specific primers, here we present the complete mt sequence of $D$. arbuscula van der Horst, 1922. Colony was sampled from Seto $\left(33^{\circ} 41^{\prime} 25^{\prime \prime} \mathrm{N} / 135^{\circ} 20^{\prime} 16^{\prime \prime} \mathrm{E}\right)$, Japan. Sequences were edited using Sequencher v. 5.1 (Sinauer Associates, Inc., Sunderland, MA) (Gene Codes) and verified under Blast search. The position of the protein-coding, rDNAs, and tRNAs genes were determined through comparison with the available homologous sequences in GenBank, and also using the Dual Organelle Genome Annotator (Wyman et al., 2004).

The entire mt genome from D. arbuscula is $19069 \mathrm{bp}$ in length (GenBank KR824937), and consists of two rRNAs

Correspondence: Marcelo Visentini Kitahara, Departamento de Ciências do Mar, Universidade Federal de São Paulo, Campus Baixada Santista, Santos, São Paulo, Brazil. E-mail: mvkitahara@unifesp.br
( $\mathrm{rnl}$ and rns), two tRNAs (trnM and trnW), and 13 protein-coding genes (ND1-6, ND4L, ATP6, ATP8, COB, and CO1-3) all arranged in the canonical scleractinian $\mathrm{mt}$ gene order (see Chen et al., 2008; Kitahara et al., 2014; Lin et al., 2014) and encoded on the same strand. No genes overlap, resulting in 18 intergenic spacers totaling $2611 \mathrm{bp}$. All protein-coding genes but ND5, ND6, ND4L, and ND3 use methionine (ATG) as the translation initiation codon. ND6 uses isoleucine (ATA) and ND5, ND4L, and ND3 use valine (GTG). TAA or TAG was verified as complete stop codons for each protein-coding gene. The sense strand of the mt genome of D. arbuscula is composed of $25.4 \% \mathrm{~A}, 13.6 \% \mathrm{C}, 23.7 \% \mathrm{G}$, and $37.3 \% \mathrm{~T}$. At $62.7 \%$ the $(\mathrm{A}+\mathrm{T})$-content is within the "average" observed for "Complex", scleractinians, but ranges from $43.7 \%$ for trnM to $69.7 \%$ for ND4L. The genes ND5 and CO1 are interrupted by group-I introns, of which that of ND5 is $11299 \mathrm{bp}$ long and engulf 11 genes, and that of $\mathrm{CO} 1$ extends for $964 \mathrm{bp}$ and contains a LAGLI-DADG motif that potentially codes for a homing endonuclease.

Nucleotide sequences of all protein-coding genes from 39 scleractinians representing the "Basal" (1), "Complex" (25), and "Robust"' (13) clades, in addition to sequences from 12 Corallimorpharia, two Actiniaria, one Antipatharia, and two Octocorallia were used to reconstruct the Anthozoa evolutionary history (Figure 1). Final alignment total is $11339 \mathrm{bp}$ of which 7545 are phylogenetically informative. Topology resulting from maximum likelihood analysis using PhyML (Sinauer Associates, Inc., Sunderland, MA) (Guindon et al., 2010) under the GTR + I + G nucleotide evolutionary model, follows the three main scleractinian clades, and places the dendrophylliids as sister group to poritids, in the "Complex" clade. 


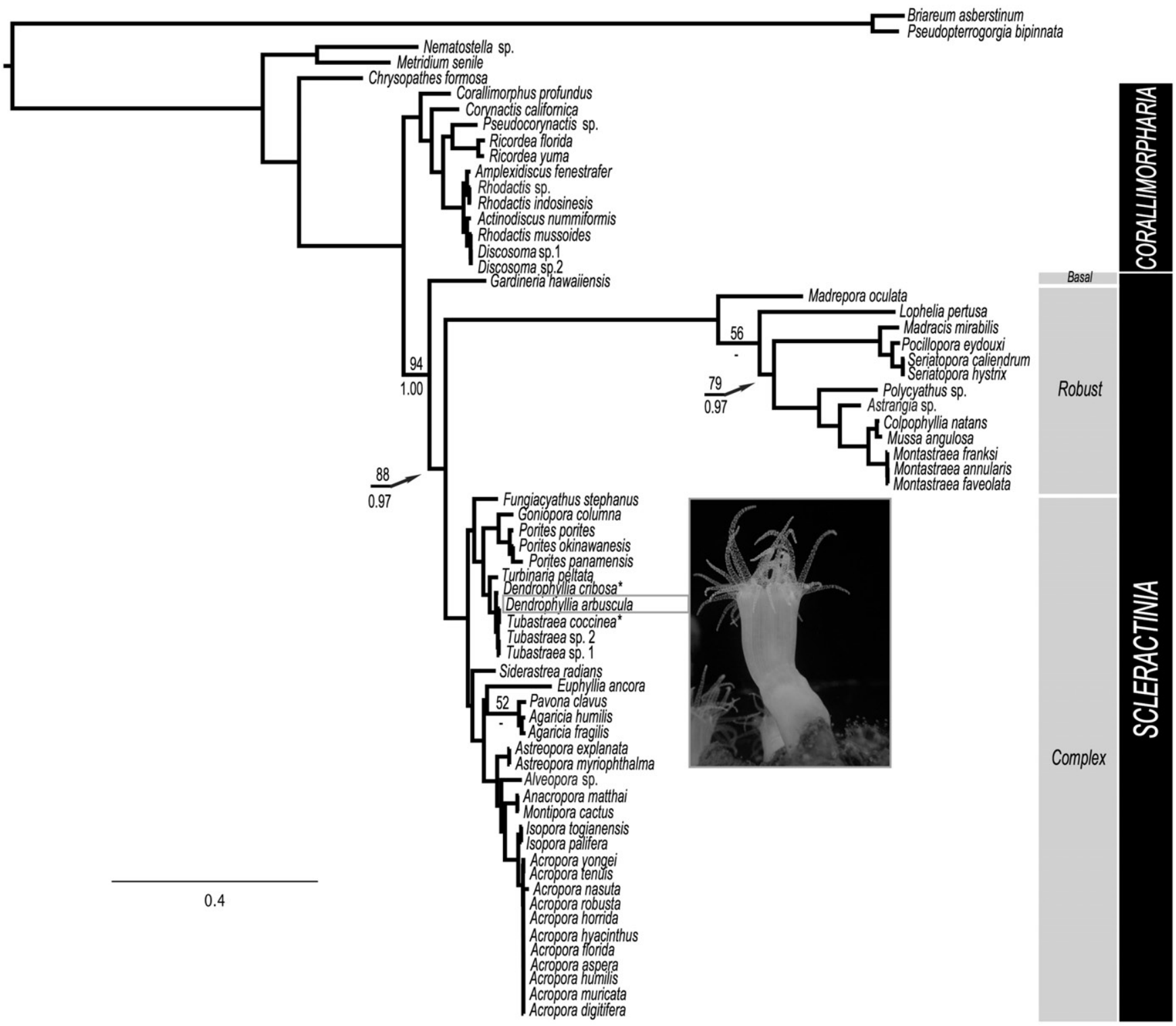

Figure 1. ML phylogeny of scleractinian corals based on all mitochondrial protein-coding genes. ML bootstrap (upper) and Sh-Like (lower) node support values are shown at each; nodes without support numbers indicate bootstrap and Sh-Like support over $\geq 98$. An asterisk following species name indicate that its sequence has not been formally published yet.

\section{Declaration of interest}

The authors report no conflicts of interest. The authors alone are responsible for the content and writing of the paper. The authors would like to thank the São Paulo Research Foundation for funding the present study (\# 2012/21583-1 to Alvaro E. Migotto; \# 2012/01771-8 to SNS).

\section{References}

Cairns SD. (1999). Species richness of recent Scleractinia. Atoll Res Bull 459:1-46.

Cairns SD. (2001). A generic revision and phylogenetic analysis of the Dendrophylliidae (Cnidaria: Scleractinia). Smithson Contrib Zool 615: $1-48$.

Cairns SD. (2007). Deep-Water Corals: An overview with special reference to diversity and distribution of deep-water scleractinian corals. Bull Mar Sci 81:311-22.

Chen C, Chiou CY, Dai CF, Chen CA. (2008). Unique mitogenomic features in the scleractinian family Pocilloporidae (Scleractinia: Astrocoeniina). Mar Biotechnol 10:538-53.

Guindon S, Dufayard JF, Lefort V, Anisimova M, Hordijk W, Gascuel O. (2010). New algorithms and methods to estimate maximum-likelihood phylogenies: Assessing the performance of PhyML 3.0. Syst Biol 59: 307-21.
Kitahara MV, Cairns SD, Stolarski J, Blair D, Miller DJ. (2010). A comprehensive phylogenetic analysis of the Scleractinia (Cnidaria, Anthozoa) based on mitochondrial CO1 sequence data. PLoS One 5:e11490.

Kitahara MV, Lin M, Forêt S, Huttley G, Miller DJ, Chen CA. (2014). The "naked coral" hypothesis revisited - Evidence for and against scleractinian monophyly. PLoS One 9:e94774.

Lin M, Luzon KS, Licuanan WY, Ablan-lagman MC, Chen CA. (2011). Seventy-four universal primers for characterizing the complete mitochondrial genomes of scleractinian coral (Cnidaria; Anthozoa). Zool Stud 50:513-24.

Lin M, Kitahara, MV, Luo H, Tracey D, Geller J, Fukami H, Miller DJ, Chen CA. (2014). Mitochondrial genome rearrangements in the Scleractinia/Corallimorpharia complex: Implications for coral phylogeny. Genome Biol Evol 6:1086-95.

Romano SL, Palumbi SR. (1996). Evolution of scleractinian corals inferred from molecular systematics. Science 271:640-2.

Shi X, Tian P, Lin R, Lan W, Niu W, Zheng X. (2014). Complete mitochondrial genome of disc coral Turbinaria peltata (Scleractinia, Dendrophylliidae). Mitochondrial DNA. [Epub ahead of print]. doi: 10.3109/19401736.2014.926506.

Stolarski J, Kitahara MV, Miller DJ, Cairns SD, Mazur M, Meibom A. (2011). The ancient evolutionary origins of Scleractinia revealed by azooxanthellate corals. BMC Evol Biol 11:2-15.

Wyman SK, Jansen RK, Boore JL. (2004). Automatic annotation of organellar genomes with DOGMA. Bioinformatics 20:3252-5. 